\title{
A Comparative Study on Women Perception and Condition In the Event of Natural Disaster and Migration: A Qualitative Study from Sindh - Pakistan Flood 2010
}

\author{
Rizwan Ali Memon \\ Mehran University of Engineering and Technology Jamshoro Sindh, Pakistan
}

\begin{abstract}
In this study, we want to compare previous and current perception and condition of migrant's women after completing ten years of emigrant at their new residential. In province of Sindh, district Jamshoro tehsil Kotri our samples, the migrant's families from Jacobabad, Shikarpur, Kashmore-Kandhkot, QamberShahdadkot and Dadu districts were migrating to adjacent areas of Kotri during 2010 due to flood. Many of them returned back to their area when recovered but a significant number from them are permanently settled in adjacent areas of Kotri. Comparing their perception and condition, we use a new technique of comparative twin questions with conceded closed and open-ended characteristics, and a qualitatively 94 migrants' women were interviewed. Results reveal high populated families are more motivated about their employment and health concerns and these facilities force them to settle permanently. Further study divulges that participation of migrants' women in socio-eco and domestic decision-making process was recorded unchanged, due to resemblance of their previous and current life standards. Our results recommend that the state intervention for the purpose migrant's processing of Passports, Computer National Identity Cards (CNICs), and issuance of Domicile and Permanent Residence Certificates (PRCs) from their current residential addresses. Their job of nature changed from agriculture to industrial that ultimately knocking the door of long-term opportunities. Hence, government should make friendly policies to facilitate migrants' families, which is essential for development of any society.
\end{abstract}

Keywords: Migrants' women; New residential; flood 2010

This is an open access article under the $C C-B Y-N C$ license

\section{INTRODUCTION}

Pakistan assumed 3rd rank in frequently flood affected countries, because of a massive part of the population living in low lying flood plains(Abbas, Amjath-Babu, Kächele, \& Müller, 2015). The Indus flood of 2010 was the direct cause of over 1800 deaths, nearly 1.7 million homes were completely damaged and displacement was occurred of 17.8 million people across the Pakistan (Purakayastha, Singh, Narwal, \& Chhonkar, 2011).The flood of 2010 was the past's ever shocking flood experience in Sindh. Economic dent estimated from $\$ 8.50 \mathrm{bn}$ to $\$ 10.80 \mathrm{bn}$, which comprise the estimated costs destroyed infrastructure, standing crops, livestock, initial recovery and relief process and other economic losses to communities as well as individual properties(Hashmi, Siddiqui, Ghumman, \& Kamal, 2012; Tariq \& Van De Giesen, 2012). The major portion of this loss was materialized in Sindh province. The Sindh province has been extremely affected in flood of 2010. The main causes of this huge damage considered an ineffective warning system and lack of preparedness, the same is still widely been practiced (Haq, Akhtar, Muhammad, Paras, \& Rahmatullah, 2012). This study suggests the amendment in current policies of public institutions who are 
issuing the national identification documents that ultimately encourage migrant families to settle permanently and not to repeat the same situation they faced in flood 2010.

Present comparative study was carried out in tehsil Kotri district Jamshoro of Province Sindh. The families who migrants from Jacobabad, Shikarpur, Kashmore-Kandh kot, Qamber-Shahdad kot and Dadu to Tahsil Kotri of district Jamshoro during flood 2010. Many of them returned back when their area retrieved and recovered but some of them are still survived can say permanently settled in different areas of Kotri, including Khuda ki Basti, Khurshed colony, Telegraph colony and Bhirya village Jamshoro. This study compares previous and current condition of migrant's women after completing ten years of flood 2010 at their new residential. Qualitatively a new technique used of comparative twin questions containing closed and open ended characteristics.

\section{LITERATURE REVIEW}

\section{Geography of Sindh province}

Sindh Province is situated in the South eastern part of the country (Lat 23-45 and Lat 28-39 N). The boundaries of Sindh province are connected with Arabian Sea in south, Baluchistan in west, India in east and Punjab is in north. Administratively province of Sindh is distributed in 29 districts (Nasir \& Akbar, 2012). Sindh's economy is mainly concerned with agriculture however; this province has some good industrial structure include textile, chemical, cement, steel and others. Most of the industries are situated in Karachi and Kotri/Hyderabad region (Amanullah \& Ahmed, 2015; Memon, Lohana, \& Naqvi, 2021).

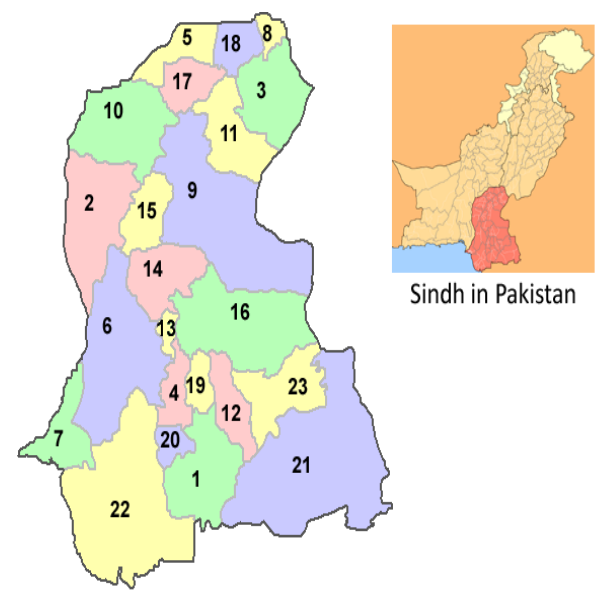

Figure 1. Sindh Province

Source: Google/encyclopeida/sindhmap

\section{Disaster risk in the Province}

Sindh province has a high risk of floods, heavy rains, sea intrusion, epidemics and droughts. Floods/rains are the most expected annual phenomenon, because topographically the land of Sindh province is flat and sited at the bottom of Indus basin (Tagar \& Shah, 2013; Tariq, van de Giesen, Janjua, Shahid, \& Farooq, 2020). The excess water of Indus River, monsoon and hill torrents comes from Balochistan which offers extra pressure in flood. The flood of 2010 was the history's ever devastating flood experience in Sindh (Ali, 2013). 


\section{Review of literature}

Natural vulnerabilities floods, rainfall, wind and storm are not occasional phenomena with unfortunate consequences (Fomby, Ikeda, \& Loayza, 2013). Each time natural hazards brings masses of population disturbance, children were excluded from schools, and increases infant mortality rate (Jonkman, 2005). Moreover, in Bangladesh and India diarrheal and AIDs diseases were reported high due to floods (Rahman, Singh Arya, Goel, \& Mitra, 2012). According to NDMA (2010) and UN (2012) many children of flood affectees' in Pakistan, never returned back to school and couldn't resume their study. Education for all (EFA) accredited that flood disaster pretense many challenges to country and compel international rank support.

In Pakistan, flood 2010 made devastating destruction, millions of people displaced and one fifth land of the country was drowned (Iqbal, 2018). Actually, vulnerability asks state intervention to do actions and make policies learn from the experiences (Jamshed, Birkmann, McMillan, Rana, \& Lauer, 2020). Vulnerabilities also lead significant challenges that may lead towards the opportunities. Furthermore, the repeated disasters lessen the ability to cope situation again and again (Uzun, Kim, \& Karanfil, 2015). Masses that displaced during the flood of 2010, some of them are trying to shift their job of nature from agriculture to industrial posture because they can't afford any other exercise that made them sound-asleep (Ainuddin, Aldrich, Routray, Ainuddin, \& Achkazai, 2013). Existing studies encapsulates some engineers and bureaucrats also placed a role in their miss judgments and poor policies that creates spillways and failure of irrigation system which cause of vulnerabilities like supra flood of 2010 in Pakistan.

\section{Literature on Women and Natural disasters}

Existing literature suggests that women bear the more burden of natural disasters as compare to men and having more capabilities of bitter pill to swallow (Ajibade, McBean, \& Bezner-Kerr, 2013). Significant population of women is playing key roles in the production of food. In Pakistan majority of women are related with informal economy and mainly depend on natural resources such as; crops, energy and water (Mustafa et al., 2015). More focused on climate change, women face more degradation and deterioration (Ullah, Nihei, Nafees, Zaman, \& Ali, 2018). Degradation refers power in decision making as men is mostly dominates in all parts of decision making. Whereas, deterioration reflects disparity on control over their wish and will of doing anything, women often sacrifice her wish for the sake of her spouse, family or community (Zakar, Zakar, \& Kraemer, 2013). A booklet issued by United Nations proves women acquire more affected by climate change as compare men, especially, rural women undergo hard disparities in access of information and decision making, which multiplies their obscurity (Watch, 2009). Poverty is connected with vulnerability and marginalization of women. In developing countries 75 percent women are living below the line of poverty (Manorom, Baird, \& Shoemaker, 2017; Shah, Ye, Abid, \& Ullah, 2017). In Pakistan, man is considered as primary breadwinner and women are mainly responsible for household chores, child and elderly care (Mumtaz, Shahid, \& Levay, 2013). Some researchers explain inequality in legal and social privileges, imbalance labor division and insufficient access to information and resources lead them more vulnerable as compare to men (Kolachi et al., 2013). Some studies suggest environmental change in resultant permanent migration is important factor for long term development of the economies (Cohen, 2005; Murrugarra, Larrison, \& Sasin, 2010). Thus, we want to investigate the perception and condition of women, who emigrant during 2010 in flood. 


\section{RESEARCH METHOD}

The study was conducted in tehsil Kotri district Jamshoro province of Sindh. A qualitative methodology semi-structure questionnaire used; 94 interviews has been taken to investigate the phenomenon. Total participants selected from the four different colonies defined in table.1.

Table.1 selected sample of area and respondents.

\begin{tabular}{|l|l|l|l|}
\hline S.NO & Name of Residence area & $\begin{array}{l}\text { Selected } \\
\text { Respondents }\end{array}$ & Date from to \\
\hline $\mathbf{1}$ & Khurshed Colony & 17 & $19-22$ Oct, 2020 \\
\hline $\mathbf{2}$ & Khuda Ki Basti & 26 & $22-26$ Oct, 2020 \\
\hline $\mathbf{3}$ & Telegraph Colony & 21 & $27-31$ Oct, 2020 \\
\hline $\mathbf{4}$ & Bhirya Village Jamshoro & 30 & $02-05$ Nov, 2020 \\
\hline
\end{tabular}

Initially, average 30 respondents were targeted from four selected colonies and total sample of 120 was decided but due to similarity in responses from the communities and smaller amount availability of migrant population especially in Khurshed colony and telegraph colony, it was concluded at 94 respondents as defined in table.1. For the purpose of data collection two professional researchers' female enumerators were hired for the period of one month from 9th Oct, 2020 to 8th Nov, 2020. Two training session was conducted on dated 12th and 14th Oct, at Mehran University Institute of Science and Technology Department (MUISTD) meeting hall. Author trained them properly about research instruments before their start of field visit process.

This study is based on first hand information, which gathered through the interviews and some existing literature by international and national agencies, government and non-governmental organizations, Provincial disaster management authority (PDMA) and National disaster management authority (NDMA). The focus of the study is to provide a concrete assessment of comparison between previous residency and current residency socio-economic condition of women after completing their 10 years. Snow ball sample technique was used in data collection process.

\section{Research instrument}

The questionnaire contains 3 sections. All are relevant with the theme of comparison their current and previous living standards and asking about challenges they are facing.

First section carried 5 questions related with migrant women's personal information such as; previous/current location name, Age, Marital status, education and total family members. Second section contains 3 comparative twin questions. The first twin question asks: "What factors influence to settle permanently in new residential?" This question was enclosed with 4 options:

1. My family can't afford another loss (lives and finance) as in flood 2010.

2. My children are getting quality education as compare to previous residency.

3. I am more comfortable in health facilities as compare to previous residency.

4. We have good opportunities of employment here as compare to previous residency.

After selection of respondent choice, enumerator has to inquire second open ended question to justify its selection, which filled in one or two open ended line.

Likewise, second twin question was practiced: "What are the differences in your role and responsibilities at domestic level?" Question comprised with the degree of changed or unchanged in their new residential settings as compare to previous residential. Question conceded with the closed options: 
1. I don't know

2. Unchanged

3. Somehow

4. Changed a lot

After opting the option, questionnaire contain an open ended few lines for justification of their selection. Similarly, third and last twin question: "What are the changes in your participation of decision making process?" This comparative question asking women's participation in decision making process with the intensity of increased or decreased in new residential settings as compare to previous settings. Question closed with 4 options:

1. Decreased

2. I don't know

3. Unchanged

4. Increased

After respondent's selection, enumerator requests for justification in next open ended question with her professionalism. This middle section is carried a central purpose of the study. Final third section contains 5 questions, related to migrants' families processing of identity documents from their current residential and inviting migrants' to suggest any favor they ought from the state at the current scenario for their betterment.

\section{Purpose of the Study}

Current study's main objective is to compare and investigate the previous and current socioeconomic conditions of migrants' women, who settled and still survived in adjacent areas of Kotri. The change in their socio-economic conditions as reflected with the change in job of nature that interrelates with the change in contribution and participation in decision making and their socio-economic role. Whole study revolves around its comparative purpose and that mission was carried with the help of research instrument.

Study's focus is on migrants' women of flood 2010, who are migrants and settled in adjacent areas of Kotri city. They have completed the tenure of 10 years in their new residency. They initially shifted on momentary purpose till their areas were recovered. According to the Assistant Commissioner Kotri, district Jamshoro, from the total migrants' population of 2010 flood; 72 percent population returned back their homes and 28 percent settled permanently here, beside Kotri city. They had started journey from flood migrants' camps and then they purchased house started dwell on rent (Ali, 2013). The aim at providing overall image of women in their new adopted settings. There are so many other queries contain current study's research instrument.

Sindh rural women, like those in other provinces of country, are even poorer than men. Further, their participation and contribution towards socio-economic activities endure unrecognized, that lead women 10 times more vulnerable as compare to other gender (Demetriades \& Esplen, 2010). Natural disasters can be considered as one of the main factors for this susceptibility. Communities were mainly survived on livestock and agriculture sector and the flood of 2010 changed their work of nature from agriculture sector to daily wages labor and daily wages cheap industrial worker. No doubt close industries have taken advantage of this phenomenon. The focus of the study is to highlight the challenges and opportunities of women, belongs to migrants' communities, those were affected by flood of 2010 in Pakistan. This study was undertaken entirely in tehsil Kotri, district Jamshoro. Using snowball sampling 
technique, a data set of triangulation was proceeded with twin technique, 94 women were interviewed from the four different resident colonies, adjacent to Kotri city.

\section{FINDINGS AND DISCUSSION}

This study investigates the changing occurred in their current living principles, values and their job of nature as compare with previous life standard and their socio-economic conditions from where they basically belong before the migration of flood 2010. The families found here are mostly come from the eastern districts of Sindh, including Jacobabad, Shikarpur, Kashmore-Kandhkot, Qamber-Shahdadkot and Dadu. Many of them returned back as their area recovered but one fourth ratio is still survived can say permanently settled in different areas of adjacent Kotri, including Khuda ki Basti, Khurshed colony, Telegraph colony and Bhirya village Jamshoro. Now they have completed of 10 years their migration and they are not willing to go back their previous areas/villages. In simple words, can say they are more comfortable at their new residential.

Table 2. Respondent's age

\begin{tabular}{|c|c|}
\hline No of Migrant's women respondents & Age \\
\hline 33 & $18-35$ \\
\hline 47 & $36-50$ \\
\hline 14 & 51 or above \\
\hline
\end{tabular}

Study's primary obligation is required a large population at their mature stage. The reason behind this is to investigate more deepen of experience of migrants' women from their previous living principles. Major portion of population is at their middle-aged. Analysis of the data reveal the differences in responses is not depends upon the age group of the women; however marital status has a significant impact on their differences in approaches and ideas. Marital status of respondents was documented.

Table 3. Respondent's Marital Status

\begin{tabular}{|c|c|}
\hline No of Migrant's women respondents & Marital status \\
\hline 19 & Unmarried \\
\hline 68 & Married \\
\hline 07 & Window/Divorced \\
\hline
\end{tabular}

Marital status and level of education are very close and interrelated. Classifying education of respondents.

Table 4. Respondent's Level of Education

\begin{tabular}{|c|c|}
\hline No of Migrant's women respondents & Level of Education \\
\hline 73 & Uneducated \\
\hline 16 & Read \& write \\
\hline 05 & Middle or above \\
\hline
\end{tabular}

Normal education of migrant's women is mainly depends upon their marital status. Majority of unmarried women were found literate. They could read and write. Last question of first section was a numeric asking the total family members group, documented as. 
Table 4. Respondent's Total Family Member

\begin{tabular}{|c|c|}
\hline No of Migrant's women respondents & Total family members \\
\hline 16 & $1-5$ \\
\hline 47 & $6-10$ \\
\hline 31 & 11 or above \\
\hline
\end{tabular}

Majority of migrants' families are settled having more family members. Flood 2010 created a panic in their minds and most of them don't want experience it again. At their previous location their job of nature was mainly concern agriculture field but at their new location they have a multiple option of employment. This leads positive sign to permanently settle at new residential.

Analysis of the second section of the questionnaire contained 3 comparative twin questions. First closed ended and then justification with open ended. First twin question asked regarding their permanent settlement to 94 women participants. "Why you were not given priority to go back and resettlement in your paternal area?" After this question, second open ended question asked to justify their selection.

Table 5. Respondent's Response to Second Section of The Questionnaire

\begin{tabular}{|c|c|c|}
\hline \multicolumn{2}{|r|}{$\begin{array}{l}\text { Why you were not given priority to go back and resettlement in your } \\
\text { paternal area? }\end{array}$} & Responses \\
\hline 1 & Our family can't afford another loss (lives and finance) as in flood 2010. & 18 \\
\hline 2 & Our children are getting good education as compare to previous residency & 07 \\
\hline 3 & We are more comfortable in health facilities as compare to previous residency. & 44 \\
\hline 4 & $\begin{array}{l}\text { We have good opportunities of employment here as compare to previous } \\
\text { residency. }\end{array}$ & 20 \\
\hline 5 & I don't Know & 05 \\
\hline
\end{tabular}

Analyses of the first and second question showed most of the respondents are happy with the health facilities are available at their new residential and this is the reason they given priority to settle permanent over here. Mrs. Allah Bachayo said:

"In 2008, my daughter in law was died in pregnancy; there was no any separate gynecological hospital or ward till the flood of 2010 happened".

Few of them point out they had hospital but in city area and takes about more than 2-hour time to access. They are more comfortable and safer here as compare to previous locations. Existing literature also suggest health facilities are important determinants for life survival. Tehsil Kotri contains some good reputation in health facilities, namely government hospitals are Taulika Kotri hospital, T.B hospital Bihar colony, Nimra cancer hospital Jamshoro and Lumhs hospital Jamshoro. Second highest 20 responses recorded towards the different opportunities of employment is available over here. Miss. Bhagbhari said:

"I have 5 brothers and 4 sisters, all brothers are employed in different fields, two are working in textile industry Kotri, one selling newspapers and two are working on their own fruit thella, father remained ill stays at home".

Whereas, in comparison of their previous living place her whole family was mainly concerned with agricultural field and now they have multiple choices of employments, additionally have easy access for employment to different industries of Sindh industrial trading estate (SITE) area Kotri, there are about 104 small to large scale industrial units and catering about more than 20 thousands employees regular basis. 
It is observed that the result of first twin question is depends on quantity of total family members. The family responses to different employment and health facilities, containing 10 or more than 10 family members as compare to 07 responses of women, who opted children education is the main cause of permanent settlement in new residential, catered less than 5 family members. 18 respondents opted they can't afford another shock like flood of 2010 and justified their answer they don't want to let their and their loves one's life again in danger.

Analyses of another twin question first was closed ended and then justify with open ended comparison of their role and responsibility at domestic level, with the degree of changed or unchanged in their new socio-economic settings. Results reveal majority of responses are unchanged and showed the domestic activities like house hold chores remain the same as per previous location. Mrs. Jumo justifying her unchanged response that:

"I think my house hold chores such as, sweeping, laundry work, preparing meals, dusting and cleaning bathroom and other child and elderly care are as same as I was in my previous residential".

Majority of women who opted unchanged option argues their role and responsibilities are unchanged, however their job in formal industrial setting is harder as compare to their previous agricultural field job. Additionally, they find difficulty to carry household chores along with their jobs, resultant violent behavior from their copartners. A short time, they have to choose one from them and mostly they decided to remain unemployed. 15 women out of 94 opted opposite answer of a lot change option. Mrs. Ghulam shabbir justified:

"Since the migration in current place I started work in Garment factory at Site area Kotri, and the household chores was shifted to my sister in-laws, although my two daughters are also able to take care of household chores".

In Sindh or more generally in Pakistan, women are characteristically the primary caregivers and spend many hours on household work than men. In rural areas, women traditionally assigned for looking after children, elderly care and house hold tasks.

Similarly, the result of the twins' questions regarding the comparison of women's participation in decision making processes in home increased or decreased in new residential. It is measured again with the same technique, first closed ended options and then asked to justify. Enumerators were professionally trained, how to handle these twins' technique to sparse the reality. Further this question was carefully assessed with the powers or rights of women at current and previous residential. Question was simple comprise of small other questions which were verbally communicated: As your job of nature changed; and family norms, roles and regulation are also modified at somehow level. Do you observe your participation in decisions of what to eat? Take care of your children school matters? Take care of family budget? And decisions of your children's marriages? Increased or decreased as compare with your previous residential.

Result of this question disclose that 41 out of 94 women's participation in decision making is unchanged as it was on their previous residential. 25 respondents said that their participation increased and 10 respondents indicate their participation decreased as compare with previous residential. Mrs. Juryo justified her opted decrease option as she said that:

"My spouse did not allow me to work here, my connections with my relatives like my parents and siblings are disconnected since the time, so I feel myself alone and my husband is not letting me to participate in any decision, still I am hoping to go back and I may join my field, friends and relatives, who make me stronger to participate in house hold decisions". 
It is hard to write her emotions, she half of the cried at the moment. Study also found some good gesture as 25 respondents said their participation increased in decision making process. According to Mrs. Khan Mohd:

"I am happy as I am contributing financially in my family's budget and my spouse also giving me priority in all household decisions from meal to our children clothes, so my participation rise in new residential".

Analyses of data also denote there is varies in living standards as per different communities. The families settled in adjacent colonies of city Kotri like Khurshed colony, telegraph colony and khuda ki basti are mostly depend on industrial employment. Women belong to bhirya village Jamshoro is mainly concern with daily wages laborer.

Majority of migrants communities are belong to Sindhi and Baloachi nations. Both nations contain strong socio-cultural perception of women. A woman has a great respect in all relations mother, wife, sister or daughter. According to Mrs. Rahim:

"It was hardest decision for my husband to let me allow for work as a maid "masi" in any other house for the sake of few bucks to survive our one or two times food, it was my first experience to work in any other family of different community and I don't want repeat those days in any cost". Mrs. Jamil:

It was very odd in both culture women go outside and participate in any labor work. According to

"Flood 2010, consequence of rising prices and inflation, stemming poverty pressure, it was necessary to contribute my share in household expenditure and initial two years (2010-11) we faced battle of our life".

Results and data analysis of the third and last section of the questionnaire uncover coldness from the state towards migrants' basic need of identity documents process. Question asked: "Do you feel difficulty in processing of your identity documents from your current residential?"

Table 6. Respondent's Response to Third Section of The Questionnaire

\begin{tabular}{|c|c|c|c|c|c|c|}
\hline Documents & Authoritarian & $\begin{array}{c}\text { Not } \\
\text { experience } \\
\text { yet }\end{array}$ & $\begin{array}{c}\text { No, } \\
\text { easy to } \\
\text { process }\end{array}$ & $\begin{array}{c}\text { Yes, in } \\
\text { somehow } \\
\text { difficulty }\end{array}$ & $\begin{array}{c}\text { Yes, a lot } \\
\text { of } \\
\text { difficulty }\end{array}$ & $\begin{array}{c}\text { Total } \\
\text { Responses }\end{array}$ \\
\hline Passports & IMPASS & 92 & 00 & 00 & 02 & 94 \\
\hline CNICs & NADRA & 11 & 04 & 23 & 56 & 94 \\
\hline $\begin{array}{c}\text { CBRCs, MC, } \\
\text { DC and } \\
\text { RCs. }\end{array}$ & $\begin{array}{c}\text { Union } \\
\text { Councils }\end{array}$ & 35 & 16 & 24 & 19 & 94 \\
\hline $\begin{array}{c}\text { Domicile } \\
\text { and PRCs }\end{array}$ & $\begin{array}{c}\text { Revenue } \\
\text { Office }\end{array}$ & 82 & 01 & 03 & 08 & 94 \\
\hline
\end{tabular}

A large number of migrants' women complain against the processing of their identity documents, 56 from 83 who experience of their close NADRA office Kotri, stated a lot of difficulty in processing of their CNICs either in fresh category or renewal. Whereas only 2 women out of 94 sample populations, experienced to visit in IMPASS office for their fresh passport but they totally denied to process and they had to go their previous locations for processing of their passports. Same behavior from the Deputy Commissioner office (Revenue Office) for their processing of domiciles and PRCs 12 women experienced to visit DC office out of 94 women 8 of them confirmed very difficulty in processing of their domiciles and PRCs and 3 said yes difficulty in somehow but got processed. Similarly, as expected from the union councils 
59 migrant's women experienced to visit out of which 43 felt difficulty in somehow and a lot during the process.

Flood 2010 hardly hit and destroyed the nature of life survival of affect tees' families and the destruction force them to not come back again in same flood jurisdictions, that is not safe at any cost. They faced so many challenges to precede these documents.

\section{CONCLUSION \& FURTHER RESEARCH}

\section{Conclusion}

This comparative study was carried out in Sindh province, district Jamshoro tehsil Kotri. The families who migrants from Jacobabad, Shikarpur, Kashmore-Kandh kot, Qamber-Shahdad kot and Dadu to TahsilKotri of district Jamshoro during flood 2010. Many of them returned back as their area recovered and 28 percent of them are permanently settled in adjacent areas of Kotri, including Khuda ki Basti, Khurshed colony, Telegraph colony and Bhirya village Jamshoro. This study compared previous and current condition of migrant's women after completing ten years of flood 2010. More populated families are more concern their health and this is the main reason they decided to settle permanently. Migrant's families job of nature totally changed from agriculture to industrial posture but all other socio-cultural and their domestic role and responsibilities remain unchanged because of similarity in their current and previous living standards. Migrants' families are still facing so many challenges in processing of their Computerized National Identity Cards (CNICs), Benazir Income Support Program (BISP) cards, Domiciles, Permanent residence certificates (PRCs) and registration in voting. National as well as local government should play their role to support and make friendly policies for the sake of migrants' families.

Technique used of comparative twin questions containing closed and open ended characteristics. Results reveal less populated families are more focused on their children's education. High populated families are worried about their employment and health concerns. Further study counts the job of nature totally changed from agriculture to industrial posture and majority of migrant are more comfortable at new location due to good health facilities and multiple employment opportunities. State intervention is required to make them more stable as they have completed their 10 years but still facing lots of challenges to survive.

\section{Recommendations}

The process of migration due to any natural disaster, is takes a lot impact on migrants' lives, have more chances of being illiterate and poor. At the hard time of flood 2010 women proved their participation shoulder to shoulder with men, and contribute in all parts of social and economic perspectives as they survived and looking this incident into opportunity.

Results reveal they can't process their identity documents easily. Their processing of CNICs and domiciles are taking so many efforts. Government should deliver a friendly policy based on an effective monitoring mechanism. Policies might be available to facilitate all applicant from all over the country but due to less vigilance apparatus and huge rushes over public offices, authoritarian of issuance of identity documents neglect migrants' families taking the advantage of their addresses, who are concern their previous locations.

National as well as local government should play their role to support and make friendly policies for the sake of migrants' families. 


\section{Limitation of the study}

The study was undertaken entirely in "Kachi abadi's" colony's women including Khuda ki basti, Khurshed colony, Telegraph colony and bhirya village Jamshoro, all these allocated in tehsil Kotri, district Jamshoro, and was limited to women who had migrated from district Dadu, Kashmore, shikarpur, shahdad kot and Jacobabad settled in the research sample area. The study therefore reflects on relevant women's condition. It does not reflect the women's condition who migrated from the flood affected area to Hyderabad and Karachi because these districts are considered in urban parts of the country and migrated communities may feel different challenges and opportunities as compare to sample colonies of this research. In addition, this study does not look in detail at the existing social and cultural (welfare) issues of women workers.

\section{REFERENCES}

Abbas, A., Amjath-Babu, T., Kächele, H., \& Müller, K. (2015). Non-structural flood risk mitigation under developing country conditions: an analysis on the determinants of willingness to pay for flood insurance in rural Pakistan. Natural Hazards, 75(3), 2119-2135.

Ainuddin, S., Aldrich, D. P., Routray, J. K., Ainuddin, S., \& Achkazai, A. (2013). The need for local involvement: Decentralization of disaster management institutions in Baluchistan, Pakistan. International Journal of Disaster Risk Reduction, 6, 50-58.

Ajibade, I., McBean, G., \& Bezner-Kerr, R. (2013). Urban flooding in Lagos, Nigeria: Patterns of vulnerability and resilience among women. Global Environmental Change, 23(6), 1714-1725.

Ali, A. (2013). Indus basin floods: Mechanisms, impacts, and management.

Amanullah, M., \& Ahmed, A. (2015). Environmental Change Impacts on Indus Riverine Forest, Sindh, Pakistan. Journal of Environmental Professionals Sri Lanka, 4(1).

Cohen, J. H. (2005). Remittance outcomes and migration: Theoretical contests, real opportunities. Studies in comparative international development, 40(1), 88-112.

Demetriades, J., \& Esplen, E. (2010). The gender dimensions of poverty and climate change adaptation. Social dimensions of climate change: Equity and vulnerability in a warming world, 133-143.

Fomby, T., Ikeda, Y., \& Loayza, N. V. (2013). The growth aftermath of natural disasters. Journal of applied econometrics, 28(3), 412-434.

Haq, M., Akhtar, M., Muhammad, S., Paras, S., \& Rahmatullah, J. (2012). Techniques of remote sensing and GIS for flood monitoring and damage assessment: a case study of Sindh province, Pakistan. The Egyptian Journal of Remote Sensing and Space Science, 15(2), 135-141.

Hashmi, H. N., Siddiqui, Q. T. M., Ghumman, A. R., \& Kamal, M. A. (2012). A critical analysis of 2010 floods in Pakistan. African Journal of Agricultural Research, 7(7), 1054-1067.

Iqbal, A. R. (2018). Flood management in Pakistan-A case study of flood 2010: NDMA.

Jamshed, A., Birkmann, J., McMillan, J. M., Rana, I. A., \& Lauer, H. (2020). The impact of extreme floods on rural communities: evidence from Pakistan Climate Change, Hazards and Adaptation Options (pp. 585613): Springer.

Jonkman, S. N. (2005). Global perspectives on loss of human life caused by floods. Natural Hazards, 34(2), 151-175.

Kolachi, H. B., Siddiqui, M. I., Memon, M. N., Memon, M. S., Abro, G. S., \& Kazi, A. (2013). Integration of Preventive and Curative Health Services for Flood Survivors by LUMHS-A Successful Health Care Model for Preparedness of Future Floods in Pakistan. JLUMHS, 12(02), 120. 
Manorom, K., Baird, I. G., \& Shoemaker, B. (2017). The World Bank, hydropower-based poverty alleviation and indigenous peoples: On-the-ground realities in the Xe Bang Fai River Basin of Laos. Paper presented at the Forum for Development Studies.

Memon, R. A., Lohana, K., \& Naqvi, I. B. (2021). Gender Pay Gap in Textile Industrial Cluster Kotri, Sindh Pakistan. South Asian Journal of Social Sciences and Humanities, 02(02), 86-100. doi: 10.48165/sajssh.2021.2208

Mumtaz, Z., Shahid, U., \& Levay, A. (2013). Understanding the impact of gendered roles on the experiences of infertility amongst men and women in Punjab. Reproductive health, 10(1), 1-10.

Murrugarra, E., Larrison, J., \& Sasin, M. (2010). Migration and poverty: Towards better opportunities for the poor: World Bank Publications.

Mustafa, D., Gioli, G., Qazi, S., Waraich, R., Rehman, A., \& Zahoor, R. (2015). Gendering flood early warning systems: the case of Pakistan. Environmental Hazards, 14(4), 312-328.

Nasir, S. M., \& Akbar, G. (2012). Effect of River Indus flow on low riparian ecosystems of Sindh: a review paper. Rec. Zool. Surv. Pakistan, 21, 86-89.

Purakayastha, T. J., Singh, B. R., Narwal, R., \& Chhonkar, P. K. (2011). Soil resources affecting food security and safety in South Asia. World Soil Resources and Food Security, 281.

Rahman, M. M., Singh Arya, D., Goel, N. K., \& Mitra, A. K. (2012). Rainfall statistics evaluation of ECMWF model and TRMM data over Bangladesh for flood related studies. Meteorological Applications, 19(4), 501-512.

Shah, A. A., Ye, J., Abid, M., \& Ullah, R. (2017). Determinants of flood risk mitigation strategies at household level: a case of Khyber Pakhtunkhwa (KP) province, Pakistan. Natural Hazards, 88(1), 415-430.

Tagar, H. K., \& Shah, S. R. A. (2013). Water resource management in Sindh: Fundamental problems and policy guideline. International Journal of Innovative Research and Development (ISSN 2278-0211), 2(2), 175-193.

Tariq, M. A. U. R., \& Van De Giesen, N. (2012). Floods and flood management in Pakistan. Physics and Chemistry of the Earth, Parts A/B/C, 47, 11-20.

Tariq, M. A. U. R., van de Giesen, N., Janjua, S., Shahid, M. L. U. R., \& Farooq, R. (2020). An engineering perspective of water sharing issues in Pakistan. Water, 12(2), 477.

Ullah, W., Nihei, T., Nafees, M., Zaman, R., \& Ali, M. (2018). Understanding climate change vulnerability, adaptation and risk perceptions at household level in Khyber Pakhtunkhwa, Pakistan. International Journal of Climate Change Strategies and Management.

Uzun, H., Kim, D., \& Karanfil, T. (2015). Seasonal and temporal patterns of NDMA formation potentials in surface waters. water research, 69, 162-172.

Watch, U. W. (2009). Fact sheet: Women, gender equality and climate change. New York.

Zakar, R., Zakar, M. Z., \& Kraemer, A. (2013). Men's beliefs and attitudes toward intimate partner violence against women in Pakistan. Violence against women, 19(2), 246-268. 